\title{
Evaluation of the antioxidant effects in vitro of the isopulegone
}

\author{
Oskar Almeida Silva ${ }^{1}$ Francisco Rodrigo de Asevedo Mendes de Oliveira $;^{2}$ Tamires Cardoso Lima ${ }^{3}$ \\ Damião Pergentino de Sousa ${ }^{3}$ Alexandre Araújo de Souza, ${ }^{1,2}$ Rivelilson Mendes de Freitas ${ }^{2, *}$ \\ ${ }^{1}$ Universidade Federal do Piaui, Departamento de Química, \\ Campus Universitário Ministro Petrônio Portella - Bairro Ininga, CEP 64049-550, Teresina, Piauí, Brasil \\ ${ }^{2}$ Universidade Federal do Piauí, Departamento de Bioquímica e Farmacologia, \\ Programa de Pós-Graduação em Ciências Farmacêuticas, Campus Universitário Ministro Petrônio Portella - Bairro Ininga, \\ CEP 64049-550, Teresina, Piauí, Brasil \\ ${ }^{3}$ Departamento de Farmácia, Universidade Federal de Sergipe, CEP 49100-000, Brasil
}

Submission Date: 3-10-2012; Review Completed: 4-11-2012; Accepted Date: 26-11-2012

\begin{abstract}
Background: Studies report that monoterpenes and their synthetic derivatives have diverse biological and pharmacological properties. Among these compounds, isopulegone present in the essential oil of various aromatic plants have been used in the production of cosmetics. Objectives: evaluated the antioxidant properties of (-)-isopulegone in vitro against the formation of reactive species using the tests thiobarbituric acid (TBARS), hydroxyl radical and nitric oxide production. Materials and Methods: The (-)-isopulegone was tested at different concentrations $(0.9,1.8,3.6,5.4,7.2 \mu \mathrm{g} / \mathrm{mL})$, and compared with trolox (positive control). We evaluated the level of lipid peroxidation induced by 2,2 '-azobis-2methyl-propanimidamide dihydrochloride (AAPH) by the amount of TBARS formed. We evaluated the in vitro effects of (-)-isopulegone against hydroxyl radical formation from Fenton reaction. In assessing production of nitric oxide, was used sodium nitroprusside on decomposition. Results: (-)-Isopulegone in the concentrations tested, was capable of preventing lipid peroxidation induced by AAPH, reducing the amount of TBARS formed. The hydroxyl radical formation was inhibited, suggesting a possible antioxidant action of this monoterpene. In the evaluation of the production of nitric oxide isopulegone decreased the formation of such compound, showing a shield in vitro profile of biomolecules such as lipids of the cell membranes from damage caused by free radicals generated. The (-)-isopulegone demonstrated strong antioxidant potential in vitro, by removal capacity against hydroxyl radicals and nitric oxide, and prevented the formation of TBARS, similarly to trolox (positive control). Conclusion: However, further studies are needed to better characterize the antioxidant properties of (-)-isopulegone, especially prominently in vitro.
\end{abstract}

Keywords: Essential oil, Hydroxyl radical, Lipid peroxidation, Monoterpene, Nitric oxide.

\section{INTRODUCTION}

Free radicals and active oxygen in the form of hydroxyl radicals, superoxide, hydrogen peroxide and singlet

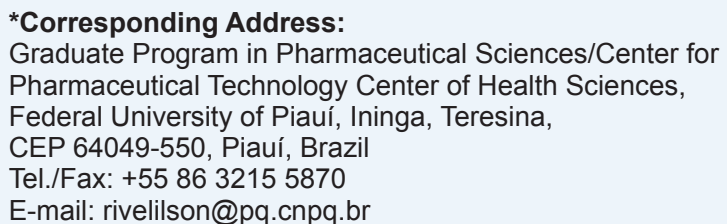

DOI: 10.5530/ax.2012.4.9 oxygen, are continuously produced in cells of the human body. ${ }^{[1,2]}$ These are atoms or molecules with unpaired electrons produced during metabolic processes continuously and act as mediators for the transfer of electrons in various biochemical reactions, playing important roles in metabolism, such as energy production, phagocytosis, regulation of cell growth and intercellular signaling. ${ }^{[3]}$

Oxidation is essential for living organisms in order to obtain the energy required for biological processes. ${ }^{[4]}$ However, too much oxidation results in oxidative stress that has deleterious effects, such as damage in DNA, proteins and cell organelles such as mitochondria and 
Oskar Almeida Silva, et al.: Evaluation of the antioxidant effects in vitro of the isopulegone

membranes, causing changes in structure and cellular functions and thus are involved in several pathologies such as neoplasias, aging, inflammatory diseases, respiratory tract diseases, cardiovascular diseases, cognitive disorders, diseases and degenerative neurological. ${ }^{[5,6]}$

The continuous production of free radicals during the metabolic processes culminated in the development of antioxidant defense mechanisms. These aim to limit the intracellular levels of reactive species, such as those derived from the metabolism of oxygen and nitrogen, and control the occurrence of damage. ${ }^{7,8]}$

In recent years, increasing attention has been devoted to the antioxidant role of natural compounds derived from plants. The use of natural antioxidants for the treatment and prophylaxis of pathologies induced by free radicals have certain advantages. Most of these agents produce few side effects because of its low toxicity. ${ }^{[9]}$ Due to the wide variety of medicinal flora, estimated at over 40,000 species, many studies are being produced on the antioxidant activity exerted by natural compounds in biological systems. Plants produce a variety of antioxidants, which act against cell damage by removing reactive oxygen species (ROS) and reactive nitrogen species (RNS). The antioxidant activity of a compound by chelating metal ions like iron or sequestering free radicals, can lead to an inhibition of lipid peroxidation, as well as the oxidation of other molecules such as proteins and DNA. ${ }^{[10,11]}$

Studies report that monoterpenes and their synthetic derivatives have several pharmacological properties. ${ }^{[12-14]}$ Among these compounds, (-)-isopulegol (2-isopropenyl-5-methylcyclohexanol) is a monoterpene alcohol, from the family of $p$-menthane (1-Isopropyl-4methylcyclohexane) ${ }^{[15]}$ that is found in the essential oil of various herbs. It has also been used in the production of cosmetics. ${ }^{[16]}$ (-)-Isopulegone (2-isopropenyl-5-methylcyclohexanone; Figure 1) is a terpenoid ketone, a cyclic compound containing two alkyl groups with trans configuration, which consists of two isoprene units. It may

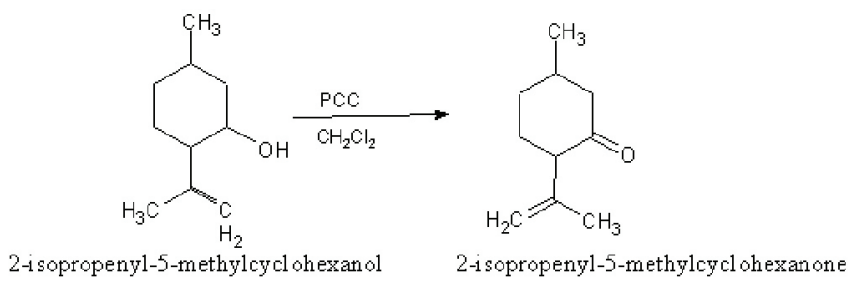

Figure 1. Possible reaction for the synthesis of isopulegone (2-isopropenyl-5-methylcyclohexanone) from the oxidation of isopulegol (2-isopropenyl-5-methylcyclohexanol). PCC $=$ Pyridinium chlorochromate . be obtained from the oxidation of (-)-isopulegol. The product formed from the oxidation of alcohols generally is an aldehyde, ketone or carboxylic acid, depending on the oxidizing agent employed and the nature of the starting alcohol. This reaction is typically catalyzed by chromium based chemicals. ${ }^{[17]}$

Through considerations and due to lack of experimental evidence and scientific research on the possible in vitro antioxidant properties of monoterpenes constituents of essential oils of medicinal plants, the present study aimed to study antioxidant effects of (-)-isopulegone in vitro.

\section{MATERIALS AND METHODS}

\section{Materials}

The monoterpenoid ketone (-)-isopulegone (2-isopropenyl5-methylcyclohexanone) has a molecular formula $\mathrm{C}_{10} \mathrm{H}_{16} \mathrm{O}$, and density $0903 \pm 0.06 \mathrm{~g} / \mathrm{cm}^{3}$. It is slightly soluble in water and soluble in alcohol. For this study the monoterpene $(-)$-isopulegone was obtained by oxidation of the alcohol (-)-isopulegol. ${ }^{[17]}$ (-)-Isopulegol was purchased from the Aldrich Chemical Company (Jacksonville, FL, USA).

\section{Evaluation of the in vitro effects of (-)-isopulegone,} against lipid peroxidation

The method used to evaluate the action of isopulegone against lipid peroxidation, a major damage caused by ROS/RNS, was accomplished through determination of reactive substances to thiobarbituric acid, known as the TBARS method. ${ }^{[18]}$

This method was used to measure the antioxidant capacity of (-)-isopulegone in a medium rich in lipids. ${ }^{[19]}$ The substrate rich in lipids used was a homogenate of egg yolk $(1 \% \mathrm{w} / \mathrm{v})$ in $50 \mathrm{mM}$ phosphate buffer ( $\mathrm{pH} 7.4)$. An aliquot of $0.5 \mathrm{ml}$ of the substrate was sonicated, and then homogenized with $0.1 \mathrm{ml}$ of (-)-isopulegone at different concentrations $(0.9,1.8,3.6,5.4,7.2 \mu \mathrm{g} / \mathrm{ml})$. Lipid peroxidation was induced by adding $0.1 \mathrm{ml}$ of 2,2'-azobis-2-methylpropanimidamide dihydrochloride (AAPH, $0.12 \mathrm{M}$ ). In the control was tested only the vehicle $(0.05 \%$ Tween 80 dissolved in $0.9 \%$ of saline solution). Reactions were performed for 30 minutes at $37^{\circ} \mathrm{C}$.

After cooling, the samples $(0.5 \mathrm{ml})$ were centrifuged with $0.5 \mathrm{ml}$ of trichloroacetic acid (15\%) at an acceleration of $1,200 \mathrm{~g}$ for 10 minutes. An aliquot of $0.5 \mathrm{ml}$ of supernatant was mixed with $0.5 \mathrm{ml}$ of thiobarbituric acid $(0.67 \%)$ and heated at $95^{\circ} \mathrm{C}$ for 30 minutes. After cooling, 
Oskar Almeida Silva, et al.: Evaluation of the antioxidant effects in vitro of the isopulegone

the absorbance of samples was measured using a UV-Vis spectrophotometer at $532 \mathrm{~nm}$. Results were expressed as percentage of TBARS formed from AAPH only (induced control). Trolox (6-hydroxy-2,5,7,8-tetramethylchromane2 -carboxylic acid) was used as a standard drug.

\section{Evaluation of in vitro effects of (-)-isopulegone, against the formation of hydroxyl radical $(\cdot \mathrm{OH})$}

Formation of hydroxyl radical $(\bullet \mathrm{OH})$ from the Fenton's reaction was quantified using the oxidative degradation of 2-deoxyribose. ${ }^{[20]}$ The principle of the test is to quantify the degradation product propanedial, also known as malonaldehyde (MDA), by its condensation with thiobarbituric acid (TBA).

The reaction was initiated by the addition of $\mathrm{Fe}^{2+}\left(\mathrm{FeSO}_{4}\right.$, $6 \mathrm{mM}$ ) to a solution containing 2-deoxyribose $5 \mathrm{mM}$, $\mathrm{H}_{2} \mathrm{O}_{2} 100 \mathrm{mM}$, and phosphate buffer $20 \mathrm{mM}$ (pH 7.4). To measure the isopulegone antioxidant activity against hydroxyl radical $(\bullet \mathrm{OH})$, different concentrations (0.9, $1.8,3.6,5.4,7.2 \mu \mathrm{g} / \mathrm{ml}$ ) of (-)-isopulegone were added to the system before addition of $\mathrm{Fe}^{2+}$. Reactions were performed for 15 minutes at room temperature, and was stationed by addition of $\mathrm{H}_{3} \mathrm{PO}_{4}$ at $4 \%(\mathrm{v} / \mathrm{v})$ followed by $1 \%$ $\mathrm{TBA}(\mathrm{w} / \mathrm{v})$ in $50 \mathrm{mM} \mathrm{NaOH}$.

The solutions were heated for 15 minutes at $95^{\circ} \mathrm{C}$, and then cooled to room temperature. The absorbance was measured at $532 \mathrm{~nm}$ and the results were expressed as equivalent MDA formed by $\mathrm{Fe}^{2+}$ and $\mathrm{H}_{2} \mathrm{O}_{2}$.

\section{Evaluation of in vitro effects of (-)-isopulegone, against the formation of nitric oxide $(\bullet \mathrm{NO})$}

In this assay nitric oxide (NO) is produced from the spontaneous decomposition of sodium nitroprusside (SNP), $\mathrm{Na}_{2}\left[\mathrm{Fe}(\mathrm{CN})_{5} \mathrm{NO}\right] \cdot 2 \mathrm{H}_{2} \mathrm{O}$ in $20 \mathrm{mM}$ phosphate buffer ( $\mathrm{pH}$ 7.4). Once formed, $\mathrm{NO}$ interacts with oxygen to produce nitrite ions $\left(\mathrm{NO}_{2}^{-}\right)$, which were detected by Griess test. $^{[21]}$

The reaction mixture $(1 \mathrm{ml})$ containing SNP $10 \mathrm{mM}$ in standard phosphate and isopulegone at different concentrations $(0.9,1.8,3.6,5.4,7.2 \mu \mathrm{g} / \mathrm{ml})$ was incubated at $37^{\circ} \mathrm{C}$ for $1 \mathrm{~h}$. An aliquot of $0.5 \mathrm{~mL}$ was taken and homogenized with $0.5 \mathrm{ml}$ of Griess reagent. The absorbance of the chromophore was measured at $540 \mathrm{~nm}$. The percentage of inhibition of $\mathrm{NO}$ production was determined by comparing the absorbance values of the negative control (NPS10 mM and vehicle only) and the preparations of the substance used in the test. Results were expressed as percentage of nitrite formed by the reaction medium.

\section{Statistical analyses}

The results were expressed as mean \pm standard error of mean (SEM) and statistical significance was determined using analysis of variance (ANOVA) followed by $t$-StudentNeuman-Keuls post hoc test with. Values were considered statistically significant at a $\mathrm{p}<0.05$. The percent inhibition determined from the following formula: $\%$ inhibition $=$ $100 \times($ control - experimental $) /$ control. ${ }^{[22]}$

\section{RESULTS AND DISCUSSION}

This study may associated the potential antioxidant of (-)-isopulegone with the their structural properties. The presence of allylic hydrogens can be associated with the antioxidant capacity of the substance. The (-)-isopulegone, by the methods used in vitro, demonstrated a good ability for reducing free radicals. This property can be assigned to one unpaired electron from the hydrogen functional group, which probably transforms the free radicals in less reactive species. The presence of allylic hydrogens can be associated with the antioxidant capacity of the substance. The (-)-isopulegone, by the methods used in vitro, demonstrated a good ability for reducing free radicals. This property can be assigned to one unpaired electron from the hydrogen alpha to the ketone functional group, which probably transforms the free radicals in less reactive species by reducing them.

The antioxidant activity was analyzed by the so, called TBARS method, which is used to quantify lipid peroxidation that corresponds to a cell membrane damage caused by oxidative stress. The AAPH, a water-soluble azo compound, is used as free radical generator. Its decomposition produces molecular nitrogen and carbonyl radicals which, in turn, react with thiobarbituric acid, resulting in the formation of TBARS. ${ }^{[23-26]}$

The (-)-isopulegone at all tested concentrations was capable of preventing lipid peroxidation, reducing the amount of TBARS formed. Similar results were obtained with trolox, a synthetic analogue of $\alpha$-tocopherol, antioxidant used as a standard, also inhibited the production of TBARS.

The concentrations used $(0.9,1.8,3.6,5.4,7.2 \mu \mathrm{g} / \mathrm{ml})$ of (-)-isopulegone, caused a $59.35 \%, 62.81 \%, 63.97 \%$; $65.04 \%$, and $65.96 \%$ reduction in the production of TBARS, respectively. The control used, Trolox, produced a decrease of $48.12 \%$ in TBARS production (Figure 2). 
Oskar Almeida Silva, et al.: Evaluation of the antioxidant effects in vitro of the isopulegone

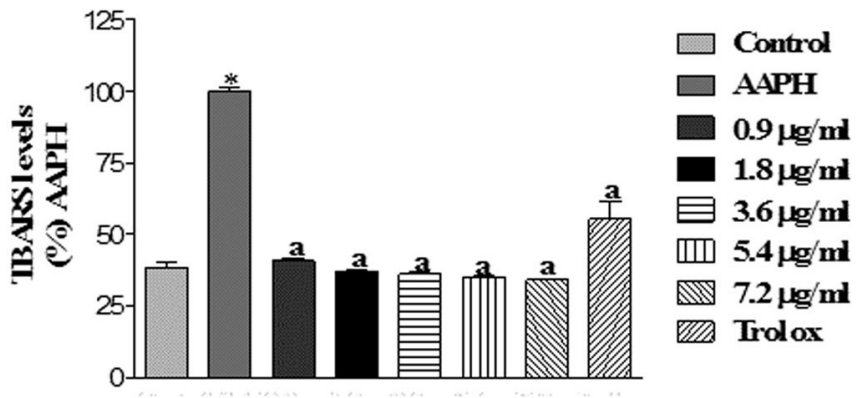

Figure 2. (-)-Isopulegone effects against the production of reactive substances to thiobarbituric acid. Values represent the mean \pm E.P.M. of the values of inhibition in vitro, $\mathrm{n}=5$ experiments in duplicate. ${ }^{\mathrm{a}} \mathrm{p}<0.001$ versus AAPH in relation to the AAPH (ANOVA and $t$-Student-Neuman-Keuls as post hoc test), ${ }^{*} \mathrm{p}<0.001$ versus AAPH compared to control (ANOVA and t-Student-Neuman-Keuls as post hoc test).

The substrate used, rich in lipids, was subjected to lipid peroxidation induced by AAPH. All concentrations of (-)-isopulegone reduced TBARS production. The results suggest that this monoterpenoid may exert an antioxidant protective effect for lipid biomolecules in vitro. The $50 \%$ inhibitory concentration $\left(\mathrm{IC}_{50}\right)$ of the compound studied against TBARS production was determined as approximately $0.52 \mu \mathrm{g} / \mathrm{ml}$ ranging from 0.278 to $0.972 \mu \mathrm{g} / \mathrm{ml}$ with a confidence interval of $95 \%$.

Comparing our results with other studies in the area, we have found that extracts from the leaves of Baccharis Dracunculifolia DC features antioxidant properties similar to those of (-)-isopulegone. The antioxidant activity of these extracts appears to be related to the presence of phenolic compounds such as flavonoids, found in most species studied. ${ }^{[27]}$ In this study, it was used the azo radical DPPH (2,2-diphenyl-1-picrylhydrazyl) as a source of free radicals. The inhibitory concentration of the extract, its ability of scavenging free radicals, was approximately $5.5 \mu \mathrm{g} / \mathrm{ml}{ }^{[28]}$

Based on the results obtained in the studies, we proposed a possible mechanism of reaction for the antioxidant action of (-)-isopulegone against the formation of lipid radical, as shown in Figure 3.

Another methodology used to evaluate the antioxidant activity of a substance is based on the ability to remove free radicals formed in less reactive species. ${ }^{[2]}$ The ability of a substance to scavenge the hydroxyl radical may be directly related to its antioxidant activity. The hydroxyl radical is a highly reactive species that can damage DNA, proteins and lipids. ${ }^{[26,30,31]}$ The hydroxyl radical is harmful to the body, since it has a very short half-life, being highly reactive attacking different types of molecules by hydrogen abstraction and addition. In DNA it can attack the

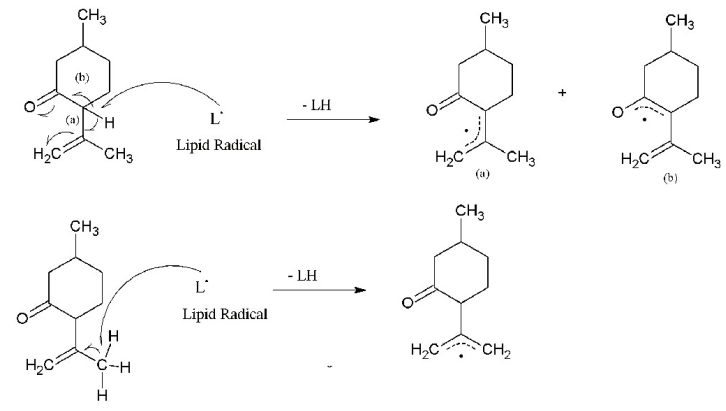

Figure 3. Possible in vitro antioxidant reaction mechanisms of (-)-isopulegone against formation of lipid radical, during lipid peroxidation.

nitrogenous bases or deoxyribose, abstracting a hydrogen atom, causing breakage of the DNA chain and generating carcinogenic or mutagenic effects. ${ }^{[32]}$

In this method the hydroxyl radical is generated by the Fenton's reaction. In the presence of the hydroxyl radical, the 2-deoxyribose is degraded to malonaldehyde, and then quantified. ${ }^{[26,30]}$

This study demonstrated that (-)-isopulegone produced the removal of hydroxyl radical, showing a significant antioxidant activity that may be able to inhibit the cellular damage caused by this radical. The trolox (standard) also significantly reduced the amount of this radical.

The concentrations of $0.9,1.8,3.6,5.4$ and $7.2 \mu \mathrm{g} / \mathrm{ml}$ of (-)-isopulegone produced a removal of the hydroxyl radical of 45.28, 48.62, 53.67, 60.19 and $63.87 \%$ in ascending order of concentrations respectively. The control used, Trolox, produced a removal of the formation of hydroxyl radical from $78.06 \%$, as seen in Figure 4 .

The $\mathrm{IC}_{50}$ of (-)-isopulegone against the production of hydroxyl radical was determined to be approximately

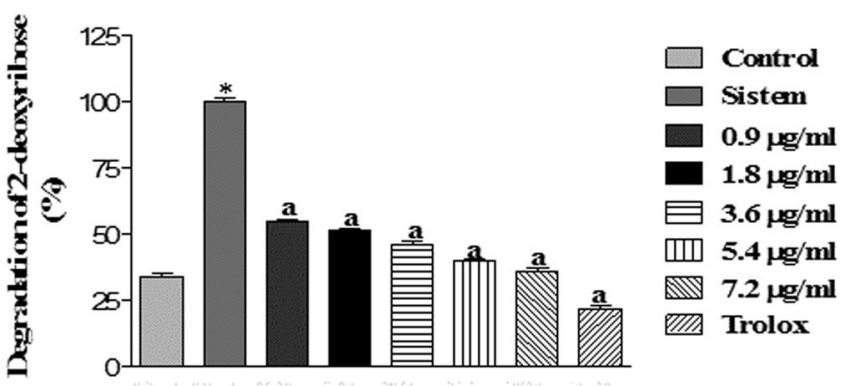

Figure 4. (-)-Isopulegone effects on the removal of hydroxyl radical. Values represent the mean \pm E.P.M. of the values of inhibition in vitro, $\mathrm{n}=5$ experiments in duplicate. ${ }^{\mathrm{a}} \mathrm{p}<0.001$ versus system in relation to the system (ANOVA and $t$-StudentNeuman-Keuls as post hoc test), ${ }^{*} \mathrm{p}<0.001$ versus system compared to control (ANOVA and $t$-Student-Neuman-Keuls as post hoc test). 
Oskar Almeida Silva, et al.: Evaluation of the antioxidant effects in vitro of the isopulegone

$0.296 \mu \mathrm{g} / \mathrm{ml}$ ranged from 0.147 to $0.596 \mu \mathrm{g} / \mathrm{ml}$ with a confidence interval of $95 \%$. Regarding the antioxidant activity in extracts of the leaves of Taraxacum officinale F.H. Wigg showed significant activity with $\mathrm{IC}_{50}$ of $4.0 \mu \mathrm{g} / \mathrm{ml}$, in this way, the lower the $\mathrm{IC}_{50}$ value, the higher the antioxidant activity of the extract. The prospect of chemical extracts identified the presence of compounds such as flavonoids, terpenes and others who may be responsible for the observed activities. ${ }^{[28]}$

Based on the removal capacity of the hydroxyl radical it was proposed a possible reaction mechanism as shown in Figure 5.

Another methodology used was the method of sequestration to reduce the formation of NO. This method is based on NO production from the decomposition of sodium nitroprusside in aqueous solution. NO, in turn, interacts with oxygen to produce nitrite ions, which can be measured by Griess reaction. ${ }^{[2]}$ These nitrite ions have a strong oxidizing power, reacting with various biological molecules, which leads to cell damage. ${ }^{[19]}$ Substances with sequestrating action for $\mathrm{NO}$ compete with oxygen, leading to reduced production of nitrite, featuring the antioxidant activity. ${ }^{[26,33]}$

In this study, (-)-isopulegone significantly decreased the production of nitrite, demonstrating again their antioxidant properties against damage caused by free radicals. ${ }^{[19]} \mathrm{NO}$ is a signaling molecule involved in many physiological and pathological processes. ${ }^{[34]}$ Studies show that NO may interact with other reactive species derived from oxygen and induce the formation of peroxynitrite which have potent cytotoxic and proinflammatory effect. ${ }^{[35]}$ Thus, the effect of isopulegone inhibiting the production of nitrite may suggest an anti-inflammatory and cytoprotective effect related to its antioxidant action that needs to be further investigated.

Therefore, the results obtained in this study show that at the concentrations used (-)-isopulegone 0.9, 1.8, 3.6, 5.4 and $7.2 \mu \mathrm{g} / \mathrm{ml}(-)$-isopulegone produced the removal of
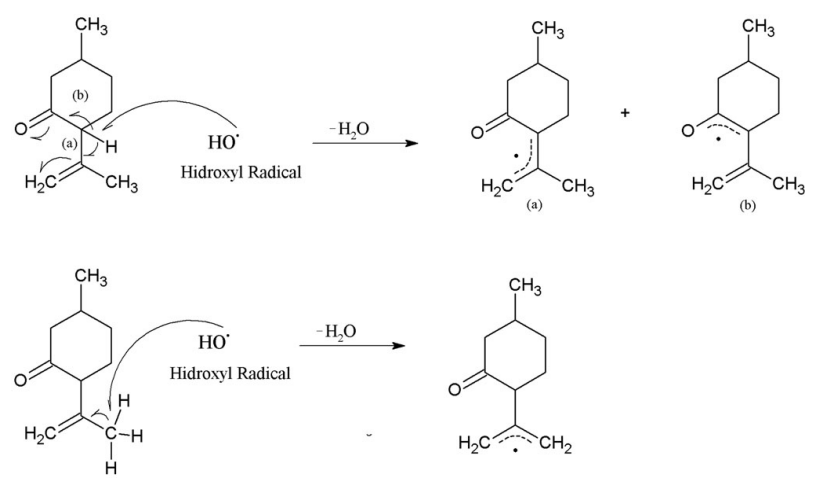

Figure 5. Possible in vitro antioxidant reaction mechanisms of (-)-isopulegone against the formation of hydroxyl radical.

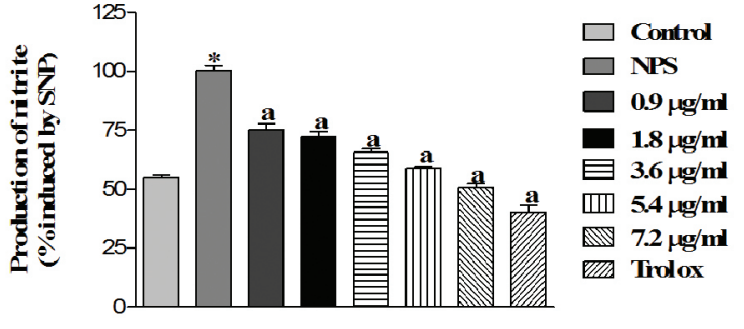

Figure 6. (-)-Isopulegone effects against the production of the metabolite nitrite by decomposition of sodium nitroprusside (SNP). Values represent the mean \pm E.P.M. of the values of inhibition in vitro, $\mathrm{n}=5$ experiments in duplicate. ${ }^{\mathrm{a}} \mathrm{p}<0.001$ versus SNP in relation to the SNP (ANOVA and $t$-Student-Neuman-Keuls as post hoc test), ${ }^{*} \mathrm{p}<0.001$ versus SNP compared to control (ANOVA and t-Student-Neuman-Keuls as post hoc test).

radical nitrite of $24,76,27.81,34.35,40.98$ and $49.18 \%$ respectively. Looking at Figure 6, the control used, Trolox, produced a removal for the formation of nitrite radical $59.76 \%$.

In turn, the $50 \%$ inhibitory concentration $\left(\mathrm{IC}_{50}\right)$ of monoterpene against the production of nitrite was determined as approximately $0.096 \mu \mathrm{g} / \mathrm{ml}$ ranging from 0.045 to $0.202 \mu \mathrm{g} / \mathrm{ml}$ with a confidence interval of $95 \%$. Studies have reported the antioxidant capacity of Laurus nobilis $\mathrm{L}$. with $\mathrm{IC}_{50}=0.76 \mu \mathrm{g} / \mathrm{ml}$ which has in its constitution the strong antioxidant eugenol, a phenolic compound (4-allyl-2-methoxyphenol), whose efficiency has been proven both in vitro and in vivo. The antioxidant of this kind can be explained by the presence of substances capable of inhibiting free radicals. ${ }^{[36]}$

The following mechanism has been proposed to demonstrate the antioxidant activity against nitrite and other reactive species generated by decomposition of $\mathrm{NO}$, as shown in Figure 7. The in vitro tests demonstrate that isopulegone was able to reduce the production of free radicals at all concentrations tested. Its antioxidant activity
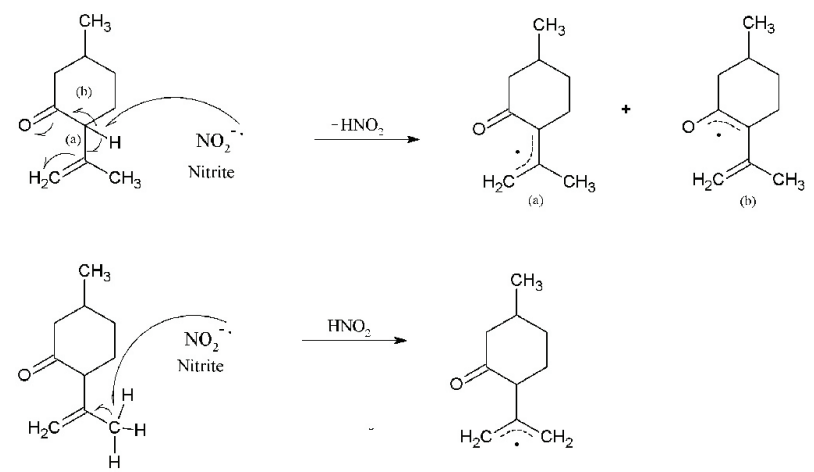

Figure 7. Possible in vitro antioxidant reaction mechanisms of (-)-isopulegone against the formation of nitrite $\left(\mathrm{NO}_{2}^{-}\right)$. 
Oskar Almeida Silva, et al.: Evaluation of the antioxidant effects in vitro of the isopulegone

may be attributed to its structural characteristics, for it is a monoterpenoid with allylic hydrogen. Probably, when it reacts with a free radical, it acts as a donor of an unpaired electron from its hydrogen atom $(\mathrm{H} \bullet)$, converting thus free radicals into less reactive species.

\section{CONCLUSION}

The results obtained in this study demonstrate that (-)-isopulegone exerts a protective antioxidant effect of lipid biomolecules in vitro, considering the methods used. More studies are needed to elucidate the possible mechanisms of action that mediate the antioxidant potential of isopulegone.

\section{REFERENCES}

1. Pérez YG, Pérez LCG, Netto RCM, Lima DSN, Lima ES. Malondialdeído e grupo sulfidrila como biomarcadores do estresse oxidativo em pacientes com lúpus eritematoso sistêmico. Rev Bras Reumatol 2012; 52:656-60.

2. Dias ASS. Papel da proteína dissulfeto isomerase na reatividade vascular a angiotensina II e noradrenalina: Envolvimento da NADPH oxidase. Tese de doutorado. Universidade de São Paulo, Brasil (2011).

3. Alves CQ, David JM, Bahia MV, Aguiar RM. Métodos para determinação de atividade antioxidante in vitro em substratos orgânicos. Quím. Nova 2010; 33:2202-10.

4. Hu W, Heo S, Wang M. J. Korean Soc. Antioxidant and anti-inflammatory activity of Kalopanax pictus Leaf. Appl. Biol. Chem 2009; 52:360-6.

5. Lefebvre PP, Malgrange B, Lallemend F, Staecker H, Moonen G, Water TRV. Mechanisms of cell death in the injured auditory system: otoprotective strategies. Audiol Neurootol 2002; 7:165-70.

6. LeiteLEA, ResendeTL, Nogueira GM, CruzIBM, SchneiderRH, GottliebMGV. Envelhecimento, estresse oxidativo e sarcopenia: uma abordagem sistêmica. Rev. Bras. Geriatr. Gerontol 2012; 15:365-80.

7. Barbosa KBF, Costa NMB, Alfenas RCG, Paula SO, Minim VPR, Bressan J. Estresse oxidativo: conceito, implicações e fatores modulatórios. Rev. Nutr 2010; 23:629-43.

8. Abrahão AS, Pereira RGFA, Sousa RV, Lima AR. Atividade antioxidante in vitro e in vivo de café bebida mole. Pesq. Agropec. Bras 2012; 47:127-33.

9. Stülp M, Clemente E, Oliveira DM, Gnas BBB. Conservação e qualidade de mirtilo orgânico utilizando revestimento comestivel a base de fécula de mandioca. Revista Brasileira de Tecnologia Agroindustrial 2012; 6:713-21.

10. Chaudhuri S, Banerjee A, Basu K, Sengupta B, Sengupta PK. Interaction of flavonoids with red blood cell membrane lipids and proteins: antioxidant and antihemolytic effects. Int J Biol Macromol 2007; 41:42-8.

11. Atkinson J, Epand RF, Epand RM. Tocopherols and tocotrienols in membranes: a critical review. Free Radical Bio Med 2008; 44:739-64.

12. Galeotti N, Mannelli LD, Mazzanti G, Bartolini A, Ghelardini C. Menthol: a natural analgesic compound. Neurosci Lett 2002; 322:145-8.

13. De Sousa DP, Nóbrega FFF, Claudino FS, Almeida RN, Leite JR, Mattei R. Pharmacological effects of the monoterpene $\alpha-\beta$-epoxy-carvone in mice. Braz. J. Pharmacog 2007; 17:170-5.

14. Silva MI, Silva MAG, Aquino MRN, Moura BA, Sousa HL, Lavor EPH, et al. Effects of isopulegol on pentylenetetrazol-induced convulsions in mice: possible involvement of GABAergic system and antioxidant activity. Fitoterapia 2009; 80:506-13.
15. Souza MVN. Utilização do tempo (n-oxil-2,2,6,6-tetrametilpiperidina) na oxidação de álcoois primários e secundários. Quim. Nova 2004; 27:287-92.

16. Bhatia SP, Mcginty D, Letizia CS, Api AM. Fragrance material review on alpha-bisabolol. Food Chem. Toxicol 2008; 46:185-9.

17. Moreira JA, Correia AG. Enantioselective synthesis of three stereoisomers of 5,9-dimethylpentadecane, sex pheromone component of Leucoptera coffeella, from (-)-isopulegol. Tetrahed Asym 2003; 14:3787-95.

18. Rosa SD, Bristot MLU, Topanotti MFL, Tomasi CD, Felisberto F, Vuolo FS, et al. Efeito da transfusão de concentrado de hemácias sobre parâmetros de inflamação e estresse oxidativo em pacientes criticamente enfermos. Rev Bras Ter Intensiva 2011; 23:30-5.

19. Guimarães AG, Oliveira GF, Melo MS, Cavalcanti SC, Antoniolli AR, Bonjardim LR, et al. Bioassay-guided evaluation of antioxidant and antinociceptive activities of carvacrol. Basic Clin Pharmacol Toxicol 2010; 107:949-57.

20. Moravia WG, Lange LC, Amaral MCS. Avaliação de processo oxidativo avançado pelo reagente de fenton em condições otimizadas no tratamento de lixiviado de aterro sanitário com ênfase em parâmetros coletivos e caracterização do lodo gerado. Quim. Nova 2011; 34:1370-7.

21. Basu S, Hazra B. Evaluation of nitric oxide scavenging activity, in vitro and ex vivo, of selected medicinal plants traditionally used in inflammatory diseases. Phytother Res 2006; 20:896-900.

22. Reanmongkol W, Matsumoto K, Watanabe H, Subhadhirasakul S, Sakai SI. Antinociceptive and antipyretic effects of alkaloids extracted from the stem bark of Hunteria zeylanica. Biol Pharm Bull 1994; 17:1345-50.

23. Zin ZM, Abdul-Hamid A, Osman A. Antioxidative activity of extracts from Mengkudu (Morinda citrifolia L.) root, fruit and leaf. Food Chem 2002; 78:227-31

24. Fitó M, De La Torre R, Covas MI. Olive oil and oxidative stress. Mol Nutr Food Res 2010; 51:1215-24.

25. Moon JK, Shibamoto T. Antioxidants assays for plant and food components. J Agric Food Chem 2009; 57:1655-68.

26. Serafini MR, Santos RC, Guimarães AG, Santos JP, Conceição Santos AD, Alves IA, et al. Morinda citrifolia Linn Leaf extract possesses antioxidant activities and reduces nociceptive behavior and leukocyte migration. J Med Food 2011; 14:1-8.

27. Osawa T. Novel natural antioxidants for utilization in food and biological systems. In: Uritani 1, Garcia VV, Mendoza EM (Eds) Post harvest biochemistry of plant food-materials in the tropics. Japan Scientific Societies Press, Tokyo, Japan 1994, 241-51.

28. Fabri RL, Nogueira MS, Dutra LB, Bouzada MLM, Scio E. Potencial antioxidante e antimicrobiano de espécies da família Asteraceae. Rev. Bras. Plantas Med 2011; 13:183-9.

29. Hoelzl C, Bichler J, Ferk F, Simic T, Nersesyan A, Elbling L, et al. Methods for the detection of antioxidants which prevent age related diseases: a critical review with particular emphasis on human intervention studies. J Physiol Pharmacol 2005; 56:49-64.

30. Huang D, Ou B, Prior RL. The chemistry behind antioxidant capacity assays. J. Agric Food Chem 2005; 53:1841-56.

31. Shukla VK, Doyon Y, Miller JC, Kelver RC, Moehle EA, Worden SE, et al. Precise genome modification in the crop species Zea maysusing zincfinger nucleases. Nature 2009; 459:437-41.

32. Barreiros ALBS, David JM. Estresse oxidativo: relação entre geração de espécies reativas e defesa do organismo. Quim. Nov 2006; 29:113-23.

33. Kawano N, ITO O, Sakagami J. Morphological and physiological responses of rice seedlings to complete submergence (flash flooding). Ann. Bot 2009; 103:161-9.

34. Quintans-Júnior LJ, Guimarães AG, Santana MT, Araújo BES, Moreira FV, Bonjardim LR, et al. Citral reduces nociceptive and inflammatory response in rodents. Rev. Bras. Farmacogn 2011; 21:1043-105.

35. De Sousa DP, Quintans-Júnior L, Almeida RN. Evolution of the Anticonvulsant Activity of $\alpha$-Terpineol. Pharm Biol 2007; 45:69-70.

36. Morais SM, Cavalcanti ESB, Costa SMO, Aguiar LA. Ação antioxidante de chás e condimentos de grande consumo no Brasil. Rev. Bras. Farmacogn 2009; 19:315-20. 